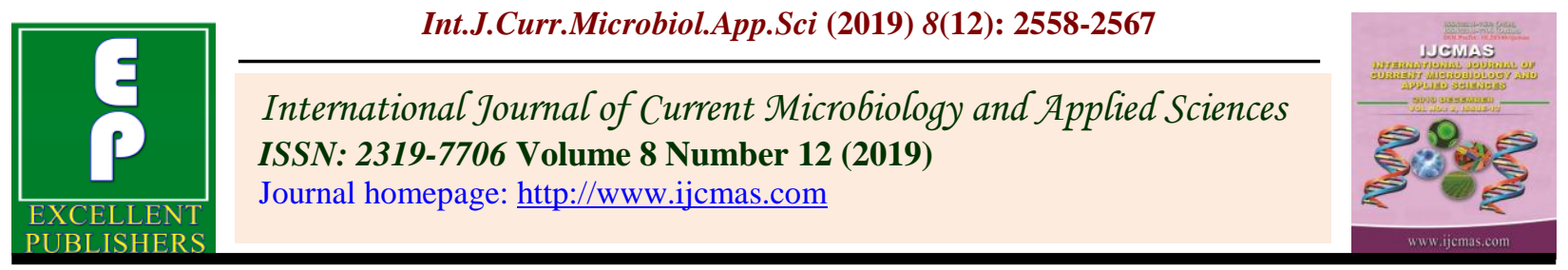

Original Research Article

https://doi.org/10.20546/ijcmas.2019.812.299

\title{
Effects of Different Doses of Fertilizer on Growth and Yield Attributes in Inter Cropping of Citronella (Cymbopogon winterianus L.)+Maize (Zea mays L.) and Bajra (Pennisetum typhoides L.)
}

\author{
Deepak Kumar*, A.K. Shrivastava and Vishram Singh
}

Department of Agronomy Chandra Shekhar Azad University of Agriculture and Technology Kanpur(U.P.), India

*Corresponding author

\section{Keywords}

Fertilizer, Growth and yield attributes, Citronella, Maize, Bajra

Article Info

Accepted:

20 November 2019 Available Online:

10 December 2019
In India, farming ranges from small to very large farms. Different farmers thus have more or less land, money and access to information and technologies. Intercropping is an excellent technique to increase total yield, higher monitory return, greater resource utilization, risk management and to fulfill the diversified need of the farmers. The present study was carried out to check the effect of different doses [sole citronella, sole maize, sole Bajra, citronella + maize $(100 \% \mathrm{RDF})$, citronella + maize $(75 \% \mathrm{RDF})$, citronella + maize $(50 \% \mathrm{RDF})$, citronella + Bajra $(100 \% \mathrm{RDF})$, citronella + Bajra $(75 \% \mathrm{RDF})$ and citronella + Bajra $(50 \% \mathrm{RDF})]$ of fertilizer on growth attribute and yield attribute. Experiment results showed that citronella sole cropping was found to be better than citronella intercropping system with maize and Bajra in same proportions (100\%, $75 \%$ and $50 \%$ RDF) in respect to the growth, yield attributes herbage and oil yields of citronella. Maize sole was found to be better in respect of growth parameters (plant population, plant height at 30,60 DAS and harvesting stage, fresh weight of cobs and dry weight of cobs), yield parameters (number of cobs/plant, length of cobs, number of kernel row/cob, number of kernel/cob and girth of cob) and yields (grain and biological) over all other citronella + maize $100 \% \mathrm{RDF}, 75 \% \mathrm{RDF}$ and 50\%RDF intercropping system in plant population proportions. Bajra sole stand was found to be better in respect of growth parameters (plant population, plant height and number of tiller/plant), yield parameters (day to 50\% ear emergence, length, girth and weight of panicle) and yields (grain and biological) over all other citronella + Bajra (2:3) intercropping system in 100\%, $75 \%$ and 50\% RDF plant population proportions. 


\section{Introduction}

Agriculture is said to be a risk profession in India, since natural factor like temperature, precipitation and pest epidemics influences crop yield and the economic fate of the farmer. Intercropping has reducing risk and also proved beneficial under adverse climatic conditions. Oil of citronella grass is one of the essential oil obtain from different species of aromatic grasses. Citronella oil is a raw material for production of geraniol, citronellal, Hydroxyl citronella and other similarly high value perfumery bases. It is also widely used as a starting material for various aromatic chemicals used in scented soaps, sprays, deodorants, detergent, polishes, mosquito repellents etc. Maize, the Queen of cereals contains about $10 \%$ protein, $4 \%$ oil, $70 \%$ carbohydrates, $2.3 \%$ crude fibre, $10.4 \%$ albuminoids and 1-4\% ash. Besides, maize grains also contains significant quantity of Vitamin A, nicotine acid, riboflavin and Vitamin E. Maize is fairly high in phosphorus and maize protein, zein is deficient in tryptophan and lysine, the two essential amino acids. It is capable of utilizing solar radiation due to its large sized leaves and has the highest photosynthetic rate. Bajra (Penisetum typhoides) is grown in around 40 countries around the world. Majorbajra producing countries are Senegal, Mali, Nigeria, Sudan, China and Uganda etc. Bajra is the fifth most important cereal crop in India. It is most important food crop mostly grown in semiarid regions, particularly in the north-western part of the country. In India, it is grown on an area of $7.9 \mathrm{~m} \mathrm{ha}$, produces $9.18 \mathrm{mt}$ with an average productivity of $11.64 \mathrm{q} /$ ha Rajasthan, Uttar Pradesh, Gujarat and Haryana contribute about 87 per cent of the total area and about 73.5 per cent of the total production comes from these states In Uttar Pradesh bajra occupies an area of about 9.41 lakh ha of which about 95 per cent is under rainfed area and Mathura, Agra, Bulandshar, Aligarh and
Farrukhabad are the important Bajra growing district (Directorate of economics and statistics and crop insurance Govt. of Uttar Pradesh 2014-15).

\section{Materials and Methods}

\section{Experimental site}

The experiment was laid out in the wellestablished experiment in the field No. 03 at Student Instructional Farm of Chandra Shekhar Azad University of Agriculture and Technology, Kanpur (U.P.) India during kharif season 2015. The farm is located in the main campus of university. The field was well levelled having good irrigation and drainage facilities. The stubble of previous crop and weeds were removed from the field by manual practice.

\section{Results and Discussion}

\section{Observations recorded during experiment}

In order to determine the effect of different treatments, a number of observations on growth characters, yield contributing characters and yield of crops (Herbs, grain, cobs etc.) oil content through oil distillation, weed population were recorded at different stages of crop growth. Since it was not possible to study the all characters in individual plants, 5 sample plants from main and intercrops of each treatment were selected randomly and tagged for further study. All the observations taken are categorized into the following groups.

In Sole and Intercrop plots, Citronella root slips were transplanted at $60 \times 60 \mathrm{~cm}$. to maintain the 2:2 row ratio. After survival of plant, plant population was studies individual in each plot. The plant population of maize and Bajra was recorded after thinning at harvest stage. The height of plants was 
measured in $\mathrm{cm}$ from ground level to the top portion of the plants. The number of tillers in all the 05 plants was counted and the average number of tillers/plant was worked out, mean values was expressed on plant basis. Leaf length of citronella, was recorded from the selected05plant in each treatment and average value was computed as final leaf length. The number of cobs/plant of maize were recorded by counting cobs in 5 sample plants and made average to obtain the cobs/plant. Cob length and girth was measured from three randomly selected cobs from sample plants. Cob length from sample plant was measured to get average length of one cob in $\mathrm{cm}$. Girth of cob was also measured from centre of cobs and average girth of cob is mentioned in $\mathrm{cm}$. Total cobs from the sample plants were weighed and mean values were recorded for weight/cob in gram. The grain rows of five randomly selected cobs were counted and the mean values were recorded for number of grains rows/cob. To count number of grains/cob five randomly selected cobs from the sample plants were collected and grains were separated through shelling by manual labour and counted. Length and Width of panicle $(\mathrm{cm})$ was measured from five randomly selected panicle for sample plants. Panicle length of Bajra from sample plant was measured to get average length of $\mathrm{cm}$. width of panicle was also measured from centre of panicle and average width of panicle is mentioned in $\mathrm{cm}$. A random sample was taken from the produce of each plot after drying and cleaning. 1000 grains of Bajra were separated from each sample and weighed. The 1000-seed weight was recorded and expressed in grams (gm). The weight of fully dried plants including cobs weight of each treatment plots were recorded and expressed as biological yield and converted in to quintal/ha. After shelling and winnowing, Grain yield of maize and Bajra was on net plot basis was recorded and finally, yield was converted in to quintal per hectare. Herbage yield \& distillation of citronella, the leaves are ready for harvest about 5-6 months after planting, and are cut with the help of sickle at $20 \mathrm{~cm}$ above the ground level. The second and subsequent harvests can be taken thereafter at 2.5-3.0 months interval during the experiment period one harvesting was done. Distillation was done by the process of steam distillation. The distillation equipment consists of a boiler in which steam is produced, a distillation tub for distilling the grass, a condenser and separators.

Data presented in Table 1 showed that the significantly lowest number of tillers/ plant, leaf length and Herbage yield were recorded in the $50 \%$ RDF of Citronella + Maize and Citronella + Bajra intercropping system. Among the intercropping and citronella sole treatment the maximum leaf length $(76.00 \mathrm{~cm})$ recorded in citronella + bajra100\%RDF intercropping system which were at par with citronella sole, $\mathrm{C}+\mathrm{M} 100 \% \mathrm{RDF}, \mathrm{C}+\mathrm{B}$ $75 \% \mathrm{RDF}$ and $\mathrm{C}+\mathrm{M} 75 \% \mathrm{RDF}$ these was significant difference. The number of tillers per plant was highest in $\mathrm{C}+\mathrm{M}$ and $\mathrm{C}+\mathrm{B}$ $100 \%$ RDF ie.85.50/plant followed by Citronella sole and $75 \%$ RDF of both systems was not difference significantly. Significantly maximum herbage yield was found in citronella sole $(88.50 \mathrm{q} / \mathrm{ha})$ in comparison to all other treatment of intercropping. Among the intercropping system significantly highest herbage yield $(69.50 \mathrm{q} / \mathrm{ha})$ recorded in $\mathrm{C}+\mathrm{M}$ gave the maximum number of tiller(85.50), Leaf length $(76.00 \mathrm{~cm})$ and herbage yield of citronella sole $(88.50 \mathrm{q} / \mathrm{ha}) \quad 1 \quad 00 \% \mathrm{RDF}$ followed by $\mathrm{C}+\mathrm{B} 100 \% \mathrm{RDF}(65.75 \mathrm{q} / \mathrm{ha})$ and C+ B 75\% RDF (65.50q/ha). The table 3 indicated that yield reduction of citronella is from 21 to $33 \%$ with $50 \%$ reduced plant population of citronella. Results indicate that different cropping systems were found to exhibit significantly variations in Citronella equivalent oil yield. Over all The significantly the highest Citronella equivalent oil yield was found in citronella sole system ie.87.5 0 
liter/ha among the intercropping system significantly highest equivalent oil yield was found in $\mathrm{C}+\mathrm{M}$ with $100 \% \mathrm{RDF}$ followed by C+B 100\% RDF. After 100\% RDF, 75\% RDF place second in position in both crops i.e. $\mathrm{C}+\mathrm{M}$ and $\mathrm{C}+\mathrm{B}$ respectively. Significantly lowest equivalent oil yield was noted in $\mathrm{C}+\mathrm{B} 50 \%$ RDF (59.25liter/ha) and $\mathrm{C}+\mathrm{M}$ 0\%RDF (53.75liter/ha). The cropping systems significantly affected the growth attributes (plant population/ plots, Leaf length $(\mathrm{cm})$ and number of tillers/plants) at the cutting time. The higher growth performance in sole crop as compared to intercropping system has also been observed by Maheshwari et al., (1998), Ram et al., (2000), Patra et al., (1990), Ansari et al., (2014), Ansari et al., (2015) and Srivastava et al., (2016). It is also clear from the result that next to Citronella sole, $\mathrm{C}+\mathrm{M}$ $(100 \%$ RDF) row ratio treatment was also recorded significantly superior in the characters like Leaf length $(\mathrm{cm})$ at the cutting time and number of tillers at the cutting time over all the treatments and at par with $\mathrm{C}+\mathrm{M}$ (75\% RDF) and $\mathrm{C}+\mathrm{B}(75 \% \mathrm{RDF})$ row ratio treatment in cutting. The intercrop was affected due to the presence of inter and intraspecific competition between main crop and the intercrop (Maize, Bajra) for growth resources such as nutrients, moisture and solar radiation due to change in crop geometry as compared to sole crop. The results of the present investigation are in close conformity with the findings of Patra et al., (1990) and Ansari et al., (2014). Sole citronella significantly recorded higher values for herbage yields than their intercropping with Maize and Bajra. This may be due to optimum spacing available for the plants. The higher growth performance in sole crop as compared to intercropping system has also been observed by Patra et al., (1990) and Ansari et al., (2014). The intercrop was affected due to the presence of inter and intra-specific competition between main crop and the intercrop (Maize and Bajra) for growth resources such as nutrients, moisture and solar radiation due to change in crop geometry as compared to sole crop. The results of the present investigation are in close conformity with the findings of Shersingh et al., (2008).

The data recorded regarding plant height at 30 , 60 DAS and harvesting stage were recorded, analyzed and presented in Table 2. Data presented in table 2 showed that the highest plant height recorded $(66.75 \mathrm{~cm})$ in Bajra sole system at $30 \mathrm{DAS}$, which is significantly highest in comparison to $\mathrm{C}+\mathrm{M}$ and $\mathrm{C}+\mathrm{B} 75 \%$ $\mathrm{RDF}, \mathrm{C}+\mathrm{M}$ and $\mathrm{C}+\mathrm{B} 50 \% \mathrm{RDF}$ but at par with Maize sole and $100 \%$ RDF of $\mathrm{C}+\mathrm{M}$ and $\mathrm{C}+\mathrm{B}$ respectively. Highest plant height $145.50 \mathrm{~cm}$ and $176.25 \mathrm{~cm}$ recorded at 60 DAS harvesting stage is at par with $100 \%$ RDF of $\mathrm{C}+\mathrm{M}$ and Bajra sole but it is significantly higher among the intercropping system of $75 \%$ and $50 \% \mathrm{RDF}$ of $\mathrm{C}+\mathrm{M}$ and $\mathrm{C}+\mathrm{B}$ system of intercropping.

Data regarding that the plant population and Days to $50 \%$ ear emergence and test weight was recorded, analyzed and presented in Table 3. The highest Plant population (23.50)was recorded in sole bajra followed by citronella + bajra inter cropping with $100 \%$ RDF and days to $50 \%$ ear emergence of bajra $(56 \%)$ in $\mathrm{C}: \mathrm{B}$ (100\%RDF).The minimum plant population(23.00) and Days to $50 \%$ ear emergence(50.00) in C:B (50\%RDF). The data recorded regarding Number of tiller per plant at 30DAS, 60 DAS and girth of plant at 60 DAS were recorded and analyzed presented in Table 4. There was non-significant difference among the treatment in relation to tillers and girth of plant. Numerically the highest Number of tillers/plant (3.00) and (3.75) recorded at 30 and 60 DAS in bajra sole treatment, respectively. The lowest Number of tiller 2.00 and 2.25 was recorded in $\mathrm{C}+\mathrm{B} 50 \% \mathrm{RDF}$ treatment at 30 and 60 DAS, respectively. The highest Girth of plant was recorded at 60DAS (6.00) $\mathrm{cm}$ in bajra sole and followed by C:B 100\% RDF 
treatment and the lowest $(4.25 \mathrm{~cm})$ in $\mathrm{C}: \mathrm{B}, 50$ $\%$ RDF treatment.

The data regarding the length of cob, girth of cob, number of kernel per cob and No. of cob pre pant were recorded, analyses and presented in Table 5. Data showed that the highest length of $\operatorname{cob}(17.75 \mathrm{~cm})$, Girth of cob(17.25 cm), Number of kernel (14.50) per row and No. of cob per plant (1.75) were observed in Maize sole treatment which was significantly better overall other treatments but at par with citronella:Maize with $100 \%$ RDF.The lowest length of cob(14.75 $\mathrm{cm})$ Girth of $\operatorname{cob}(14.00 \mathrm{~cm})$, number of kernel/row (12.25) and no. of cob per plant (1.25) were observed in C:M2:2 row ratio with $50 \%$ RDF.

The data regarding fresh weight and, dry weight of cob and number of kernel per cob were recorded analyzed and presented in table 5. Data showed that the highest significantly fresh weight $(147.50 \mathrm{~g})$, dry weight $(133.50 \mathrm{~g})$ and number of kernel / cob(366.75)was recorded in maize sole treatment followed by citronella:Maize $100 \%$ RDF which was significantly superior over $75 \%$ and $50 \%$ RDF treatment. The lowest fresh weight $(139.25 \mathrm{~g})$, dry weight $(124.25 \mathrm{~g})$ and number of kernel (354.00) per row of cob recorded inC+M50\%RDF in treatment. Data recorded regarding biological yield and grain yield were recorded analyzed, presented in Table 5. Data represented in table 5 showed that sole cropping of maize gave significantly highest biological yield $(233.95 \mathrm{q} / \mathrm{ha})$ and grain yield (44.02q/ha), over all other treatments. Among the intercropping treatment citronella+Maize with $100 \%$ RDF gave the highest biological $(124.47 \mathrm{q} / \mathrm{ha})$ and grain yield $(23.85 \mathrm{q} / \mathrm{ha})$ is significantly highest intercropping to 75 and $50 \%$ RDF.

The lowest biological yield (118.02q/ha) and grain yield $(17.40 \mathrm{q} / \mathrm{ha})$ were recorded in citronella + Maize with 50\%RDF treatments. Application of $100 \%, 75 \%$ and $50 \%$ RDF produced $54.18,46.16$ and $39.52 \%$ grain yield to that sole maize crop, respectively, while the plant population of maize of $50 \%$ to that of its sole cropping. The plant population recorded was non- significant but highest plant population recorded in Maize sole followed by 2:2 row ratio of Citronella + Maize with $100 \%$ RDF intercropping system. Growth parameters of maize were significantly influenced due to various combinations of cropping systems. The plant height recorded at 30, 60 DAS and harvesting stage significantly higher values with maize sole followed by $\mathrm{C}+\mathrm{M}(2: 2)$ with $100 \% \mathrm{RDF}$ and $\mathrm{C}+\mathrm{M} 75 \%$ RDF. Numerically the highest plant population $\left(11.25 / \mathrm{m}^{2}\right)$ has been recorded in sole Maize there was no significant difference among the treatment but at par with $\mathrm{C}+\mathrm{M}$ $100 \% \mathrm{RDF}$ followed the $75 \% \mathrm{RDF}$.

The highest length of cob $(17.75 \mathrm{~cm})$, Girth of cob $(17.25 \mathrm{~cm})$, Number of kernel (14.50) per row and No. of cob per plant (1.75) were observed in Maize sole treatment which was significantly better overall other treatments but at par with citronella+Maize with $100 \%$ RDF. The lowest length of cob (14.75 $\mathrm{cm})$ Girth of cob $(14.00 \mathrm{~cm})$, number of kernel /row (12.25) and no. of cob per plant (1.25) were observed in $\mathrm{C}+\mathrm{M} \quad(2: 2)$ with $50 \%$ RDF.Intercropping system. This could be attributed due to the dissimilar conditions of plant growth and development for maize in sole cropping as compared to intercropping system, Similar findings were also reported by (Adhikari et al., 2005; Mayaka et al., (2006), Marer et al., 2007). While, the number of cob/plant, length of cob and number of kernel row/cob was not influenced significantly by various types of cropping combination of maize with citronella. Sole cropping of maize gave significantly highest biological yield (233.95q/ha) and grain yield (44.02q/ha), over all other treatments. 
Table.1 Effect of the treatments on plant leaf length, number of tillers and herbage and equivalent oil yield of citronella

\begin{tabular}{|c|c|c|c|c|}
\hline Treatments & $\begin{array}{l}\text { Leaf length } \\
(\mathrm{cm})\end{array}$ & $\begin{array}{l}\text { Number of } \\
\text { tillers/plant }\end{array}$ & $\begin{array}{c}\text { Herbage } \\
\text { yield (q/ha) }\end{array}$ & $\begin{array}{c}\text { Equivalent Oil } \\
\text { yield }\left(\mathrm{Lha}^{-1}\right)\end{array}$ \\
\hline Citronella Sole & 75.50 & 84.25 & 88.50 & 87.50 \\
\hline C:M(100\% RDF) & 75.50 & 85.50 & 69.50 & 68.25 \\
\hline $\mathrm{C}: \mathrm{M}(75 \% \mathrm{RDF})$ & 74.50 & 83.50 & 65.50 & 60.75 \\
\hline C:M(50\%RDF) & 72.50 & 79.50 & 59.50 & 59.75 \\
\hline $\mathrm{C}: \mathrm{B}(\mathbf{1 0 0 \%} \mathrm{RDF})$ & 76.00 & 85.50 & 65.75 & 65.50 \\
\hline C:B (75\%RDF) & 75.50 & 83.25 & 61.00 & 60.00 \\
\hline C:B(50\%RDF) & 70.50 & 80.50 & 59.50 & 59.25 \\
\hline SEm \pm & 0.573 & 0.733 & 1.512 & 0.612 \\
\hline$C D(p=0.05)$ & 1.705 & 2.180 & 4.494 & 1.819 \\
\hline
\end{tabular}

Table.2 Effect of different treatments on plant height at 30, 60 and harvesting stage of maize and Bajra

\begin{tabular}{|l|c|c|c|}
\hline \multirow{2}{*}{ Treatments } & & Plant height (cm) & \\
\cline { 2 - 4 } & 30 DAS & 60 DAS & At Harvesting \\
\hline Maize sole & 65.75 & 145.50 & 176.25 \\
\hline Bajra sole & 66.75 & 144.50 & 175.75 \\
\hline C:M (100\% RDF) & 65.50 & 145.00 & 176.00 \\
\hline C:M (75\% RDF) & 64.00 & 143.25 & 173.50 \\
\hline C:M (50\% RDF) & 62.50 & 140.50 & 170.75 \\
\hline C:B (100\% RDF) & 66.25 & 144.25 & 172.50 \\
\hline C:B (75\% RDF) & 64.25 & 141.75 & 170.75 \\
\hline C:B (50\% RDF) & 62.75 & 139.00 & 0.569 \\
\hline SEm \pm & 0.611 & 0.467 & 1.675 \\
\hline CD (P= 0.05\%) & 1.798 & 1.375 & \\
\hline
\end{tabular}

Table.3 Effect of different treatments on plant population and days to $50 \%$ ear emergence of Bajra

\begin{tabular}{|l|c|c|c|c|}
\hline Treatments & $\begin{array}{c}\text { Plant } \\
\text { population }\end{array}$ & $\begin{array}{c}\text { No of } \\
\text { tillers/plant }\end{array}$ & $\begin{array}{c}\text { Girth of plant } \\
\text { at 60 DAS }\end{array}$ & $\begin{array}{c}\text { Days to 50\% ear } \\
\text { emergence of bajra }\end{array}$ \\
\hline Bajra Sole & 23.50 & 3.75 & 6.00 & 54.75 \\
\hline C:B(100\%RDF) & 23.25 & 3.50 & 5.75 & 56.00 \\
\hline C:B (75\% RDF) & 23.00 & 3.00 & 5.00 & 53.50 \\
\hline C:B (50\% RDF) & 23.00 & 2.25 & 4.25 & 50.00 \\
\hline SEm \pm & 0.375 & 0.322 & 0.372 & 0.746 \\
\hline CD (P= $\mathbf{0 . 0 5 \% )}$ & 1.199 & 1.032 & 1.192 & 2.388 \\
\hline
\end{tabular}


Table.4 Effect of different treatments on Length of cob in $(\mathrm{cm})$, Girth of cob in $(\mathrm{cm})$, total number of kernel/row of cob and No. of cob/plant in Maize

\begin{tabular}{|c|c|c|c|c|}
\hline \multirow[t]{2}{*}{ Treatments } & \multirow{2}{*}{$\begin{array}{l}\text { Length of } \\
\text { cob }(\mathrm{cm})\end{array}$} & \multirow{2}{*}{$\begin{array}{l}\text { Girth of } \\
\text { cob }(\mathrm{cm})\end{array}$} & \multicolumn{2}{|c|}{ Number of row and cob/plant of maize } \\
\hline & & & kernel/row of cob & cob/plant \\
\hline Maize Sole & 17.75 & 17.25 & 14.50 & 1.50 \\
\hline C:M (100\%RDF $)$ & 17.25 & 17.00 & 14.25 & 1.75 \\
\hline C:M (75\% RDF) & 15.75 & 14.50 & 13.00 & 1.50 \\
\hline C:M (50\% RDF) & 14.75 & 14.00 & 12.25 & 1.25 \\
\hline SEm \pm & 0.433 & 0.314 & 0.333 & 0.288 \\
\hline $\mathrm{CD}(\mathrm{P}=0.05 \%)$ & 1.385 & 1.006 & 1.066 & NS \\
\hline
\end{tabular}

Table.5 Effect of different treatments on fresh weight of cob (gm.), dry weight of cob (gm.), and number of kernel/cob of maize

\begin{tabular}{|l|c|c|c|c|c|}
\hline Treatments & $\begin{array}{c}\text { Fresh weight } \\
\text { of cob(gm) }\end{array}$ & $\begin{array}{c}\text { Dry weight } \\
\text { of cob } \mathbf{( g m})\end{array}$ & $\begin{array}{c}\text { Number of } \\
\text { kernel/cob }\end{array}$ & $\begin{array}{c}\text { Biological } \\
\text { yield (q/ha) }\end{array}$ & $\begin{array}{c}\text { Grain yield } \\
\text { (q/ha) }\end{array}$ \\
\hline Maize Sole & 147.50 & 133.50 & 366.75 & 233.95 & 44.02 \\
\hline $\begin{array}{l}\text { C:M } \\
(\mathbf{1 0 0 \%} \text { RDF) }\end{array}$ & 143.50 & 128.50 & 362.00 & 124.47 & 23.85 \\
\hline C:M (75\% RDF) & 140.75 & 125.75 & 359.50 & 121.02 & 20.32 \\
\hline C:M) (50\% RDF) & 139.25 & 124.25 & 354.00 & 118.02 & 17.40 \\
\hline SEm \pm & 0.645 & 0.677 & 0.842 & 14.271 & 0.530 \\
\hline CD (P= 0.05\%) & 2.065 & 2.165 & 2.695 & 45.656 & 1.697 \\
\hline
\end{tabular}

Table.6 Effect of different treatments on Length of panicle $(\mathrm{cm})$, Width of panicle $(\mathrm{cm})$, Harvest index and Test weight of Bajra

\begin{tabular}{|c|c|c|c|c|c|c|}
\hline Treatments & $\begin{array}{c}\text { Panicle } \\
\text { Length } \\
\text { (cm) }\end{array}$ & $\begin{array}{l}\text { Width of } \\
\text { panicle } \\
(\mathrm{cm})\end{array}$ & $\begin{array}{c}\text { Test } \\
\text { weight } \\
\text { (g) }\end{array}$ & $\begin{array}{c}\text { Biological } \\
\text { yield } \\
\text { (q/ha) }\end{array}$ & $\begin{array}{c}\text { Grain } \\
\text { yield } \\
\text { (q/ha) }\end{array}$ & $\begin{array}{c}\text { Harvest } \\
\text { index } \\
(\%)\end{array}$ \\
\hline Bajra Sole & 25.50 & 18.50 & 12.00 & 170.10 & 35.50 & 20.87 \\
\hline C:B (100\% RDF) & 24.50 & 17.50 & 12.00 & 72.70 & 19.30 & 26.54 \\
\hline C:B (75\% RDF) & 22.50 & 16.00 & 10.00 & 69.75 & 17.95 & 25.73 \\
\hline C:B (50\%RDF) & 20.75 & 15.25 & 9.00 & 68.27 & 17.50 & 25.63 \\
\hline SEm \pm & 0.554 & 0.747 & 0.50 & 0.568 & 0.264 & 0.123 \\
\hline $\mathrm{CD}(\mathrm{P}=0.05 \%)$ & 1.773 & 6.289 & NS & 1.818 & 0.846 & 0.394 \\
\hline
\end{tabular}

Among the intercropping treatment citronella + Maize with $100 \%$ RDF gave the highest biological (124.47q/ha) and grain yield $(23.85 \mathrm{q} / \mathrm{ha})$ is significantly highest intercropping to $\mathrm{C}+\mathrm{M} 75 \%$ and $\mathrm{C}+\mathrm{M} 50 \%$ RDF. The lowest biological yield (118.02q/ha) and grain yield (17.40q/ha) were recorded in citronella + Maize with $50 \%$ RDF treatments. Similar results also reported by Bhagat (2002), Myaka et al., (2006) and Ansari et al., (2014). 
Data regarding length of panicle, width of panicle, Test weight and harvesting index were recorded, analyzed and presented in table 6. Numerically the highest length of panicle $(25.50 \mathrm{~cm})$ width of panicle $(18.50 \mathrm{~cm})$ were recorded in bajra sole treatment and harvest index (26.54\%) were recorded in bajra $100 \%$ RDF treatment which followed by C:B75 \% RDF but the lowest length of panicle $(20.75 \mathrm{~cm})$ width of panicle $(15.25 \mathrm{~cm})$ were recorded in $\mathrm{C}: \mathrm{B} 50 \% \mathrm{RDF}$ in treatment and minimum harvest index $(20.87 \%)$ in Bajra sole. There was no significant difference in test weight among the treatments. Data regarding that biological yield $\left(\mathrm{qha}^{-1}\right)$ and grain yield $\left(\mathrm{qha}^{-1}\right)$ were recorded, analyzed and presented in Table 6 . The highest biological yield(170.10 q/ha) and grain yield (35.50 q/ha) was recorded in Bajra sole treatment which were significantly superior over all treatment Among the intercropping combination significantly of C+B with $100 \%$ RDF were superior over $50 \%$ RDF. Application of 100, 75 and 50\% RDF produced $54.37,50.56$ and $49.30 \%$ grain yield of bajra to $100 \%$ of sole crop respectively. The plant population recorded was nonsignificant but the highest plant population recorded in Bajra sole followed by of Citronella + Bajra (2:3) $100 \%$ RDF intercropping system. Growth parameters of bajra were significantly influenced due to various combinations of cropping systems. The growth parameters viz., plant height (cm). The highest significantly plant height $\mathrm{C}+\mathrm{B}$ (2:3) was recorded in sole bajra $(66.75 \mathrm{~cm})$ followed by $\mathrm{C}+\mathrm{B}(2: 3) 100 \% \mathrm{RDF}$ (66.25) which was significantly higher over all other combinations of RDF treatment intercropping system and number of tiller per plant differ non-significantly this was might be due to competitive environment between main crop and the intercrop in respect of growth resources such as moisture, solar radiation and nutrient owing to differential growth habit of base (citronella) and intercrop
(Bajra) are in agreement with the present investigation. Cropping system significantly affected yield attributes of Bajra viz., length of panicle, girth of panicle and grain yield. Difference in yield of base crop and intercrop is due to different fertilizer doses proportions and row ratio. The test weight did not influence by cropping system. It is thus obvious that the conditions for growth and development of Bajra in intercropping and solid stand were identical being of different growth habit (canopy, height, growth duration etc.) could not put any competition for citronella. This was also reflected in the growth attributes of citronella. Thus the growth behaviour of the crop performed in a similar way for development activities of plants was reflected in yield attributes and yields of Bajra. Kurlekar et al., (1980), Desale et al., (2000), Chellamuthu (2000) and Velayudham et al., (2011).

On the basis of experimental result conducted during kharif season (2015) following conclusion can be done. Citronella sole cropping was found to be better than citronella intercropping system with maize and Bajra in same proportions $(100 \%, 75 \%$, and $50 \% \mathrm{RDF}$ ) in respect to the growth, yield attributes herbage and oil yields of citronella. Maize sole was found to be better in respect of growth parameters (plant population, plant height at 30,60 DAS and harvesting stage, fresh weight of cobs and dry weight of cobs), yield parameters (number of cobs/plant, length of cobs, number of kernel row/cob, number of kernel/cob and girth of cob) and yields (grain and biological) over all other sole Maize, citronella + maize $100 \%$ RDF, $75 \%$ RDF and 50\%RDF intercropping system in plant population proportions. Bajra sole stand was found to be better in respect of growth parameters (plant population, plant height and number of tiller/plant), yield parameters (day to $50 \%$ ear emergence, length, girth and weight of panicle) and yields 
(grain and biological) over all other citronella + Bajra (2:3) intercropping system in $100 \%$, $75 \%$ and $50 \%$ RDF plant population proportions. In combination of citronella + Maize $100 \%$ RDF intercropping system is better than all other suitable combination citronella + Bajra intercropping system, respectively. Intercropping of kharif crop with citronella, the highest citronella equivalent oil yield was found in citronellat maize $100 \%$ RDF followed by $75 \%$ and $50 \%$ RDF system, respectively.

\section{References}

Adhikari, S., Chakraborty, T. and Bagchi, D.K. (2005). Bio-economic evaluation of maize (Zea mays L.) and groundnut (Arachis hypogaea) intercropping in drought prone areas of Chotanagpur plateau region of Jharkhand. Indian Journal of Agronomy 50(2): 113-115.

Anonymous (2014-15).Directorate Economics and Statistics and Crop insurance, Govt. of Uttar Pradesh.

Ansari, M.H., Ansari, M.A., Srivastava, A.K., and Khan, Naushad (2014). Crop diversification through citronella based cropping system. The Indian Journal of Agricultural Sciences 84(12): 155-157.

Ansari, M.H., Verma, B.K., Ansari, M.A., Mishra, Dushyant, Srivastava, A.K., Khan, Naushad and Saquib, Mohd. (2015). Impact of cropping pattern on growth, yield attributes and system productivity of citronella (Citronella winterianus) pulses intercropping system in Central India. Indian Journal of Agricultural Sciences, 85(3): 392396.

Bhagat, R.P. (2002). Intercropping of pigeon pea and maize under rainfed condition. Journal of Research, Birsa Agricultural University, 14(2): 233-235.

Chellamuthu, V. (2000). Effect of bio fertilizers and inorganic fertilizers on the fodder yield of bajra (Co.8).Madras Agricultural Journal, 87(6): 183-185.

Desale, J.S., Bhilare, R.L., Pathan, S. H. and Babar, R.M. (2000).Response of multicut fodder bajra varieties to nitrogen fertilizer levels. Journal of Maharashtra Agricultural Universities, 25(1): 74-75.

Kurlekar, V.G., Gayke, T.S. and Sondge, V.D. (1980). Fertilizer grade formulation for hybrid bajra (BJ-104), Journal of Maharashtra Agricultural Universities, 5(2): 128-140.

Maheshwari, S.K., Sharma, R.K. and Gangrade, S.K., (1998). Response of Palmarosa (Cymbopogon martini var. motio) to biofertilizer, nitrogen and phosphorus in a shallow black soil under rainfed condition. Indian Journal of Agronomy, 43: 175-178.

Marer, S.B., Lingaraju, B.S., and Shashidhara, G.B. (2007).Productivity and economics of maize and pigeonpea intercropping under rainfed conditions in northern transitional zone of Karnataka. Karnataka Journal of Agriculture Science, 20(1): 1-3.

Myaka, F.M., Sakala, W.D., Adu-Gyamfi, J.J., Kamalongo, D., Ngwira, A., Odgaard, R., Nielsen N.E. and Jensen, H.H. (2006). Yields and accumulations of $\mathrm{N}$ and $\mathrm{P}$ in farmer-managed intercrops of maize-pigeonpea in semi-arid Africa. Plant Soil 285: 207220.

Patra, B.C., Mandal, B.K. and Mandal, B.B. (1990). Profitability of maize-legume intercropping system. Indian Agriculturist, 34: 227-233.

Ram, Muni, Ram, Dasha, Prasad, Arun and Kumar, Sushil (2000). Productivity of citronella Java (Cymbopogon winterianus) with Spring Legume Intercrops under Subtropical Environment. Journal of Essential Oil Research, 10(3): 269-275. 
Shersingh, Narayan, Om, Yadav, R.K. Chauhan, N.K. and Lohani, H. (2008). Effect of different plant geometry on growth, yield and quality of citronella (Cymbopogon winterianus). Journal of Medicinal and Aromatic Plant Sciences, 30 (3): 267-269.

Srivastava A.K., Singh Vishram, Verma V.K., Chaudhary Sanjai, Pyare Ram, Verma B.K. and Parihar G.S. (2016). Economic viability of citronella based
inter-Cropping system in central plain zone of Uttar Pradesh. International Research Journal of Natural and Applied Sciences, 3(4): 136-150.

Velayudham, K., Babu, C., Iyanar, K. and Kalamani, A. (2011). Impact of plant geometry and fertilizer levels on Bajra Napier hybrid grass. Indian Journal of Agricultural Sciences, 81 (6):575-577.

\section{How to cite this article:}

Deepak Kumar, A.K. Shrivastava and Vishram Singh. 2019. Effects of Different Doses of Fertilizer on Growth and Yield Attributes in Inter Cropping of Citronella (Cymbopogon winterianus L.)+Maize (Zea mays L.) and Bajra (Pennisetum typhoides L.). Int.J.Curr.Microbiol.App.Sci. 8(12): 2558-2567. doi: https://doi.org/10.20546/ijcmas.2019.812.299 